\title{
Risk Factors for Atrial Fibrillation Recurrence in Patients Undergoing Ablation
}

\author{
Ablasyon Yapılan Hastalarda Atriyal Fibrilasyon Rekürrensi için Risk Faktörleri
}

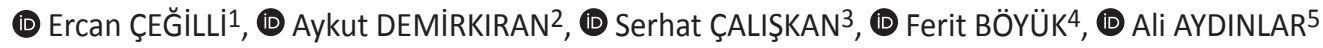 \\ ${ }^{1}$ Arnavutköy State Hospital, Clinic of Cardiology, Istanbul, Turkey \\ ${ }^{2}$ Tekirdağ Çorlu State Hospital, Clinic of Cardiology, Tekirdağ, Turkey \\ ${ }^{3}$ Bahçelievler State Hospital, Clinic of Cardiology, Istanbul, Turkey \\ 4 istanbul Yedikule Chest Diseases and Thoracic Surgery Training and Research Hospital, Clinic of Cardiology, Istanbul, Turkey \\ ${ }^{5}$ Bursa Uludağ University Faculty of Medicine, Department of Cardiology, Bursa, Turkey
}

\begin{abstract}
Aim: The current study aimed to investigate the predictors of recurrence in patients with paroxysmal atrial fibrillation (AF) undergoing cryoballoon ablation.

Materials and Methods: This study was conducted with the participation of the patients who underwent cryoballoon ablation between October 2013 and March 2016. Patients' medical records were retrospectively evaluated. Patients were divided into two groups as those with AF recurrence and those without AF recurrence.

Results: A total of 68 patients undergoing cryoballoon ablation were included in the study. The mean age of the patients was $57.3 \pm 12$ years, and $32 \%$ were male. Concomitant conditions included coronary artery disease in 25 patients (36.8\%), diabetes mellitus in 9 (13.2\%), hypertension in 46 $(67.6 \%)$, and history of cerebrovascular event in $3(4.4 \%)$. During the early period involving the initial three months, $A F$ recurrence was found in 16 patients (23.5\%), while $52(76.5 \%)$ remained in the sinus rhythm during the follow-up. There were significant differences between two groups in left atrium size $(38 \pm 5.3$ and $44 \pm 6.6, p=0.003)$, left atrial appendage (LAA) flow rate [38 (24-62) cm/sec and $28(22-55) \mathrm{cm} / \mathrm{sec}, \mathrm{p}=0.001]$, presence of pulmonary venous anomaly [5 (9.6\%) and $6(37.5 \%), p=0.016]$, the number of antiarrhythmic drugs before the ablation $(1.78 \pm 0.7$ and $2.43 \pm 0.5$, $\mathrm{p}=0.002)$, interventricular septal thickness $(11 \pm 1.7 \mathrm{~mm}$ and $12 \pm 1.47 \mathrm{~mm}, \mathrm{p}=0.008)$, left ventricular posterior wall thickness (11 $\pm 0.9 \mathrm{~mm}$ and $12 \pm 1.3$ $\mathrm{mm}, \mathrm{p}=0.007)$, and left ventricular mass ( $195 \pm 51 \mathrm{~g}$ and $181 \pm 37.9 \mathrm{~g}, \mathrm{p}=0.028$ ).

Conclusion: According to the results, AF recurrence after ablation was found to be associated with the use of multiple antiarrhythmic drugs before the ablation, increased left atrial diameter, the reduced flow rate in the LAA, presence of a pulmonary venous anomaly, increased interventricular septal thickness, left ventricular posterior wall thickness, and left ventricular mass.
\end{abstract}

Keywords: Atrial fibrillation, cryoballoon ablation, pulmonary vein isolation, left atrium

\section{öz}

Amaç: Çalışmamızda kriyobalon ablasyon uygulanan paroksismal atriyal fibrilasyon (AF) tanılı hastalarda nüksün prediktörlerinin saptanması amaçlandı.

Gereç ve Yöntem: Ekim 2013-Mart 2016 tarihleri arasında kriyobalon ablasyon uygulanan hastalar değerlendirildi. Hastaların tıbbi kayıtları retrospektif olarak incelendi. Hastalar işlem sonrası AF nüksü gelişen ve AF nüksü olmayan şeklinde iki gruba ayrıldılar.

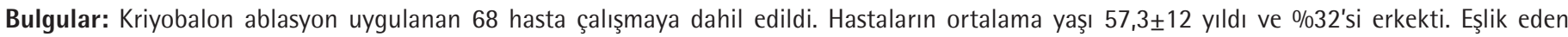
durumlar arasında 25 hastada $(\% 36,8)$ koroner arter hastalığı, 9'unda $(\% 13,2)$ diabetes mellitus, 46'sında $(\% 67,6)$ hipertansiyon ve 3 hastada 
serebrovasküler olay öyküsü yer almıştır $(\% 4,4)$. İlk üç ayı kapsayan erken dönemde 16 hastada $(\% 23,5)$ AF nüksü saptanırken, 52 hastada $(\% 76,5)$ AF nüksü saptanmadı. İki grup arasında sol atriyum boyutu $(38 \pm 5,3 \mathrm{~mm}$ ve $44 \pm 6,6 \mathrm{~mm}, \mathrm{p}=0,003)$, sol atriyal apendiks (LAA) akım hızı [38 (24-62) $\mathrm{cm} / \mathrm{sec}$ ve $28(22-55) \mathrm{cm} / \mathrm{sec}, p=0,001]$, pulmoner venöz anomali varlığı $[5(\% 9,6)$ ve $6(\% 37,5), p=0,016]$ ve işlem öncesi kullanılan antiaritmik ilaç sayısı $(1,78 \pm 0,7$ ve $2,43 \pm 0,5, p=0,002)$ açısından anlamlı farklılıklar saptandı. Sol ventrikül septum $(11 \pm 1,7 \mathrm{~mm}$ and $12 \pm 1,47 \mathrm{~mm}, \mathrm{p}=0,008)$ ve arka duvar kalınlığı $(11 \pm 0,9 \mathrm{~mm}$ and $12 \pm 1,3 \mathrm{~mm}, \mathrm{p}=0,007) \mathrm{AF}$ rekürrensini öngörmede istatistiksel olarak anlamlı bulundu. $\mathrm{AF}$ nüksü olan ve olmayan hastalarda sol ventrikül kitlesi sırasıyla $195 \pm 51 \mathrm{~g}$ ve $181 \pm 37,9 \mathrm{~g}$ olarak saptandı ve fark istatistiksel olarak anlamlıydı $(\mathrm{p}=0,028)$.

Sonuç: Ablasyon sonrası AF nüksünün öngördürücüleri arasında işlem öncesinde öyküde çoklu antiaritmik ilaç kullanımının olması ile ekokardiyografide artmış sol atriyal çapı, azalmış LAA akış hızı, pulmoner venöz anomali saptanması, artmış interventriküler septal kalınlık, artmış sol ventrikül arka duvar kalınlığı ve artmış sol ventrikül kitlesi sayılabilir.

Anahtar Kelimeler: Atriyal fibrilasyon, kriyobalon ablasyon, pulmoner ven izolasyonu, sol atrium

\section{INTRODUCTION}

Atrial fibrillation (AF) is a supraventricular arrhythmia occurring in the atrium that is associated with irregular ventricular responses. AF is the most common type of persistent cardiac arrhythmia observed in 1 to $2 \%$ of the general population'. Although AF may lead to symptoms such as palpitations, fatigue, polyuria, dizziness, exertion dyspnea, chest pain, hypotension, and syncope, a significant proportion of patients with AF rhythm may be asymptomatic. $\mathrm{AF}$ is associated with a 5-fold increased risk of stroke ${ }^{3}$. Cardiac and non-cardiac factors associated with $\mathrm{AF}$ include chronic alcohol intake, cardiac valvular disease, CAD, heart failure (HF), left ventricular hypertrophy, diabetes mellitus (DM), HT, hyperthyroidism, pulmonary embolism, chronic obstructive pulmonary disease, surgical intervention, hypertrophic or dilated cardiomyopathy or congenital cardiac diseases ${ }^{1,4}$. The triggering focus originates from the pulmonary veins (PV) in $90 \%$ of the cases with paroxysmal AF (PAF). Other identified foci include superior vena cava, coronary sinus, and the Marshall ligament ${ }^{5,6}$. The primary therapeutic method in AF ablation is based on the electrical isolation of PVs from LA. The European Society of Cardiology 2016 AF guidelines recommend catheter ablation to be performed in specialized centers by properly trained electrophysiologists for patients with symptomatic PAF recurrences during antiarrhythmic therapy, for whom the preferred therapeutic modality is rhythm control treatment ${ }^{2}$.

In this study, the predictors of AF recurrence were investigated in 68 patients who underwent cryoablation due to symptomatic PAF.

\section{MATERIALS AND METHODS}

A retrospective file review was performed and outpatient medical records were evaluated, yielding the information of 68 patients who underwent cryoballoon ablation due to a diagnosis of symptomatic PAF between October 2013 and March 2016. Diagnoses of ischemic stroke or recurrent AF after the procedure were ascertained by telephone calls and through the review of clinical records. The first 3 months following the procedure were defined as the blind period and $A F$, atrial flutter, or episodes of atrial tachycardia during this period were considered as early AF recurrence. Episodes after the first 3 months were considered as recurrence.

Patients under 18 years of age and those with persistent $A F_{\text {, }}$ serious valvular disease, and thrombus in LA, pregnant women, and those with active neoplasm, prosthetic cardiac valve, implantable cardiac rhythm devices were excluded from the study.

In our center, procedures were performed under sedation with midazolam. The Seldinger technique was used for access via the left femoral vein and artery, and the right femoral vein. Access to the left atrium was performed under fluoroscopy with transseptal puncture with a modified Brockenborough needle accompanied by transesophageal echocardiography. The Flaxcath (metronik) brand steerable transseptal catheter was directed to the left atrium over the guide wire. Arctic front $^{\oplus}$ and arctic front advance ${ }^{\oplus}$ (metronik) brand cryoablation balloon was directed through this sheath. PV circular mapping catheter through balloon the Achieve catheter was directed. Following left atrial puncture, anticoagulation was achieved using heparin with a target ACT of 300-350 seconds. After complete occlusion of PVs was ensured, a 5-minute standard cooling procedure was carried out by pumping a freezing agent (N2O) into the balloon. While ablation was performed in right PVs, continuous phrenic nerve stimulation at a low rate was performed in the superior vena cava, in conjunction with manual palpation of the contractions in the diaphragmatic area. After two freezing procedures with a minimum duration of five minutes in each PV, the procedure was terminated. One day after the cryoballoon ablation, transthoracic echocardiography was performed to rule out pericardial effusion, and patients were discharged. Treatment with oral anticoagulants and antiarrhythmic agents was planned to be continued for a minimum duration of 3 months following the cryoballoon ablation procedure, after which anticoagulant treatment was scheduled based on the CHA2DS2-VASc risk assessment.

The study was approved by the Uludağ University Local Ethics Committee for Clinical Research with decree no: 2016-5/21 and approval date: 29.11.2019. 


\section{Statistical Analysis}

Statistical Package for Social Sciences for Windows 23.0 software pack was used for the statistical assessment. Descriptive statistics were expressed as mean, standard deviation, median, minimum, and maximum. Categorical variables were expressed as numbers and percentages. The Shapiro-Wilk test was used to test whether the data had a normal distribution. The t-test was employed for variables with normal distribution and the Mann-Whitney $U$ test was used for comparisons between the two groups. Logistic regression analysis was performed to evaluate the association between variables tested and the recurrence. A p value $<0.05$ was considered statistically significant.

\section{RESULTS}

A total of 68 patients undergoing cryoablation due to PAF between October 2013 and March 2016 were included in the study. Patients were followed up for a mean duration of 22 months (8-37). The 68 patients included in the study were stratified into two groups as those who had AF recurrence and those who remained in sinus rhythm after the blind period of the initial three months. Of the 68 patients in the study, 32 $(47.1 \%)$ were male and 36 (52.9\%) were female. The mean age of the overall patient group was $57.3 \pm 12$ years. With regards to cardiovascular risk factors, 25 patients $(36.8 \%)$ had CAD, 9 (13.2\%) had DM, 46 (67.6\%) had HT, and $3(4.4 \%)$ had a history of cerebrovascular event. Among all patients, the mean CHA2DS2-VASc score was $2.2 \pm 1.39$, and the mean number of antiarrhythmic drugs the patients received was $1.94 \pm 0.7(0-3)$ (Table 1).

Transthoracic echocardiography and transesophageal echocardiography performed before the procedure showed a median LA size, left ventricular ejection fraction, and LAA flow rate of $39.5 \pm 6.0 \mathrm{~mm}, 62 \pm 5.7 \%$, and $36.5(22-62) \mathrm{cm} / \mathrm{sec}$, respectively. The median duration of fluoroscopy was $14 \pm 2.5$ minutes. The success rate defined as successful ablation in three or PVs was $100 \%$. PV anomaly (left or right-sided common PV) was identified in eleven patients (16.2\%).

During the early period involving the initial three months, AF recurrence was found in 16 patients (23.5\%), while 52 (76.5\%) remained in the sinus rhythm during the follow-up. According to the evaluation of demographic characteristics of the

Table 1. Demographics and clinical characteristics of study subjects

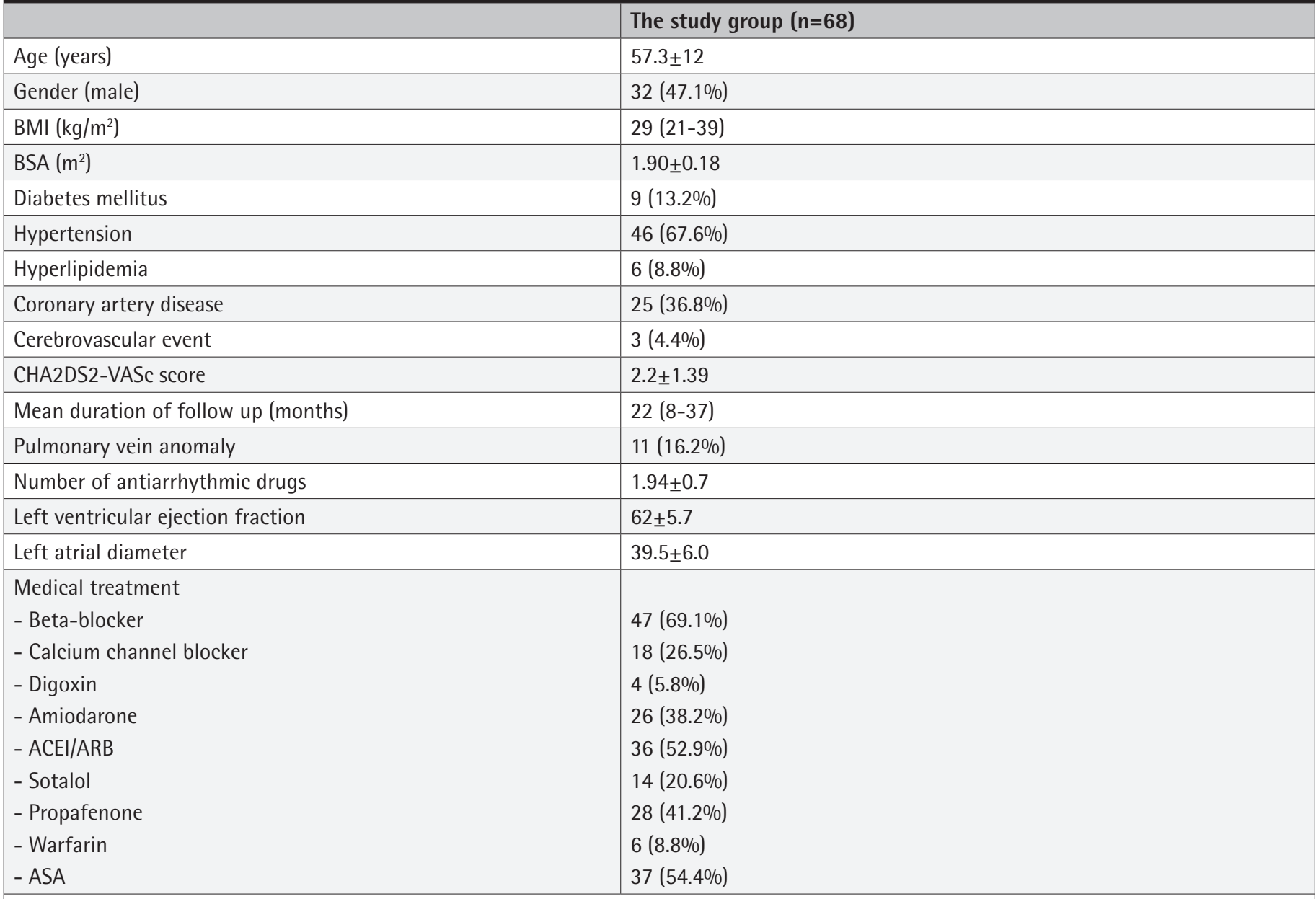

BMI: Body mass index, BSA: Body surface area, CHA2DS2-VASc: Heart failure, hypertension, age, diabetes, history of stroke, vascular disease, female gender, ACEl: Angiotensin converting enzyme inhibitor, ARB: Angiotensin receptor blocker, ASA: Acetylsalicylic acid 
patients, of the 16 patients with AF recurrence, 5 (31.3\%) were female and $11(68.7 \%)$ were male, while the corresponding figures among the 52 subjects with no recurrence included 31 (59.6\%) female and 21 (40.4\%) male. There were no statistically significant differences between the groups with regards to gender distribution ( $p>0.05$ ) (Table 2).

Again, no statistical differences between patients who had or did not have AF recurrence were observed in terms of cardiovascular risk factors such as diabetes, hypertension, hyperlipidemia, coronary artery disease, and cerebrovascular event history ( $p>0.05$ ) (Table 2).

Before the procedure, the number of antiarrhythmic drugs the patients received was $2.43 \pm 0.5(2-3)$ and $1.78 \pm 0.7(0-3)$ in those with and without AF recurrence, respectively. The number of antiarrhythmic drugs used before the procedure was significantly higher among patients who developed AF recurrence compared to those who did not $(p=0.002)$ (Table 2$)$.

Of the 16 patients with AF recurrence, 37.5\% (6) had an AF episode during the early period of the first three months while this percentage was $11.5 \%$ (6) among the 52 patients who had no AF episodes during the same period. An AF episode during the early period of the first three months was a significant predictor for AF recurrence $(p=0.027)$. The number of prior cardioversions was significantly higher among those with AF recurrence than those without AF recurrence $(p<0.001)$ (Table 2$)$.

LA diameter in patients with and without AF recurrence was $44 \pm 6.6 \mathrm{~mm}$ and $38 \pm 5.3 \mathrm{~mm}$, respectively. LA diameter was higher in the group with AF recurrence compared to the group without $A F$ recurrence with a statistically significant difference $(p=0.003)$. Septum and posterior wall thickness of the left ventricle measured in the parasternal long-axis were found to be statistically significant in predicting AF recurrence $(p=0.008$ and 0.007 , respectively). LV mass in patients with and without AF recurrence was $195 \pm 51 \mathrm{~g}$ and $181 \pm 37.9 \mathrm{~g}$, respectively. The difference in $\mathrm{LV}$ mass between the two groups was statistically significant $(p=0.028)$. LAA flow rate determined by transesophageal echocardiography in patients with and without AF recurrence was $28(22-55) \mathrm{cm} / \mathrm{sec}$ and 38 (24-62) $\mathrm{cm} / \mathrm{sec}$, respectively. The difference in LAA flow rate between the two groups was statistically significant $(p<0.001)$ (Table 3).

\begin{tabular}{|c|c|c|c|}
\hline & No $A F$ recurrence $(n=52)$ & AF recurrence $(n=16)$ & $p$ value \\
\hline Age (year) & $57.5 \pm 12.3$ & $61.5 \pm 11.5$ & 0.158 \\
\hline Gender (male) n (\%) & $21(40.4 \%)$ & $11(68.8 \%)$ & 0.084 \\
\hline $\mathrm{BSA}\left(\mathrm{m}^{2}\right)$ & $1.90 \pm 0.18$ & $1.98 \pm 0.17$ & 0.183 \\
\hline BMI $\left(\mathrm{kg} / \mathrm{m}^{2}\right)$ & $28.9(21.5-39.1)$ & $29.2(25.5-39.8)$ & 0.241 \\
\hline Hypertension n (\%) & $35(67.3 \%)$ & $11(68.8 \%)$ & 0.914 \\
\hline Hyperlipidemia n (\%) & $5(9.6 \%)$ & $1(6.3 \%)$ & 1.000 \\
\hline Coronary artery disease $\mathrm{n}(\%)$ & $16(30.8 \%)$ & $9(56.3 \%)$ & 0.65 \\
\hline Cerebrovascular event n (\%) & $2(3.8 \%)$ & $1(6.3 \%)$ & 0.559 \\
\hline COPD n (\%) & $5(9.6 \%)$ & $1(6.3 \%)$ & 1.000 \\
\hline Total number of antiarrhythmic drugs before procedure & $1.78 \pm 0.7$ & $2.43 \pm 0.5$ & 0.002 \\
\hline \multicolumn{4}{|l|}{ Use of drug before the procedure $\mathrm{n}(\%)$} \\
\hline - Amiodarone & $18(34.8)$ & $8(50)$ & 0.268 \\
\hline - Metoprolol & $20(28.4)$ & 15 (93.7) & 0.021 \\
\hline - Propafenone & $14(26.9)$ & $5(31.2)$ & 0.453 \\
\hline - Sotalol & 0 & $2(12.5)$ & 0.010 \\
\hline - Flecainide & 0 & $1(6)$ & 0.022 \\
\hline History of cardioversion & $0(0-3)$ & $1(0-4)$ & 0.001 \\
\hline AF episode within the first three months & $6(11.5 \%)$ & $6(37.5 \%)$ & 0.027 \\
\hline \multicolumn{4}{|l|}{ Use of drug after the procedure $n(\%)$} \\
\hline
\end{tabular}


While six patients (37.5\%) had a pulmonary anomaly in the AF recurrence group, the number of corresponding figures was five (9.6\%) among those without AF recurrence. Pulmonary anomalies were more common in the group with AF recurrence compared to the group without $A F$, with a statistically significant difference $(p=0.016)$ (Table 4).

No statistically significant difference was found between the patients who did or did not develop AF recurrence in terms of laboratory parameters such as complete blood count, renal function tests, thyroid function tests, C-reactive protein, erythrocyte sedimentation rate, and uric acid ( $p>0.05)$ (Table 5).

\section{DISCUSSION}

PV isolation for the management of PAF is performed either by radiofrequency (RF) or cryoballoon ablation. The reported success rate for ablation in patients with persistent AF is lower compared to that in PAF patients. In a meta-analysis involving

\begin{tabular}{|c|c|c|}
\hline No $\mathrm{AF}$ recurrence & AF recurrence & $p$ value \\
\hline $181 \pm 37.9$ & $195 \pm 51$ & 0.028 \\
\hline $97 \pm 17.7$ & $104 \pm 22.3$ & 0.075 \\
\hline $21.4 \pm 3$ & $22.1 \pm 2.6$ & 0.515 \\
\hline $46 \pm 3.5$ & $46 \pm 4.3$ & 0.660 \\
\hline $38 \pm 5.3$ & $44 \pm 6.6$ & 0.003 \\
\hline $11 \pm 0.9$ & $12 \pm 1.3$ & 0.007 \\
\hline $62 \pm 3.96$ & $64 \pm 9.2$ & 0.306 \\
\hline $6(11.5 \%)$ & $1(6.3 \%)$ & 1.000 \\
\hline $25(19-45)$ & 31 (20-39) & 0.111 \\
\hline $38(24-62)$ & $28(22-55)$ & $<0.001$ \\
\hline
\end{tabular}

Table 4. Pulmonary vein anatomy and procedural characteristics in patients undergoing cryoablation

\begin{tabular}{|l|l|l|l|}
\hline & No AF recurrence & AF recurrence & p value \\
\hline Duration of fluoroscopy (min) & $26.5 \pm 6.2$ & $25 \pm 5.8$ & 0.304 \\
\hline Total cooling time (sec) & $1920(960-3200)$ & $1910(960-3200)$ & 0.836 \\
\hline Pulmonary vein anomaly & $5(9.6 \%)$ & $6(37.5 \%)$ & 0.016 \\
\hline Upper PV freezing temperature, left - ${ }^{\circ} \mathrm{C}$ & $48 \pm 6.9$ & $50 \pm 7.0$ & 0.454 \\
\hline Lower PV freezing temperature, left - ${ }^{\circ} \mathrm{C}$ & $45 \pm 7.1$ & $48 \pm 7.3$ & 0.319 \\
\hline Upper PV freezing temperature, right - ${ }^{\circ} \mathrm{C}$ & $48 . \pm 6.6$ & $49 \pm 6.6$ & 0.922 \\
\hline Lower PV freezing temperature, right - ${ }^{\circ} \mathrm{C}$ & $41 \pm 5.6$ & $47 \pm 6.3$ & 0.001 \\
\hline AF: Atrial fibrillation, PV: Pulmonary vein & & & \\
\hline
\end{tabular}

\section{Table 5. Distribution of laboratory findings across the groups}

\begin{tabular}{|l|l|l|l|}
\hline & No AF recurrence & AF recurrence & p value \\
\hline Creatinine $(\mathrm{mg} / \mathrm{dL})$ & $0.73 \pm 0.24$ & $0.70 \pm 0.1$ & 0.919 \\
\hline GFR $(\mathrm{mL} / \mathrm{min})$ & $109.5 \pm 33$ & $113.5 \pm 25$ & 0.603 \\
\hline Uric acid $(\mathrm{mg} / \mathrm{dL})$ & $4.8 \pm 1.36$ & $4.2 \pm 1.56$ & 0.76 \\
\hline CRP $(\mathrm{mg} / \mathrm{dL})$ & $0.45 \pm 1.71$ & $0.52 \pm 0.5$ & 0.939 \\
\hline ESR $(\mathrm{mm} / \mathrm{h})$ & $10(2-68)$ & $8(3-62)$ & 0.467 \\
\hline Leukocyte count $\left(10^{3} / \mu \mathrm{L}\right)$ & $8 \pm 3.16$ & $6.8 \pm 3.7$ & 0.452 \\
\hline Hemoglobin $(\mathrm{g} / \mathrm{dL})$ & $13.2 \pm 1.61$ & $13.6 \pm 1.52$ & 0.670 \\
\hline LDL cholesterol $(\mathrm{mg} / \mathrm{dL})$ & $115 \pm 43$ & $116 \pm 27$ & 0.836 \\
\hline HDL cholesterol $(\mathrm{mg} / \mathrm{dL})$ & $43 \pm 13$ & $36 \pm 6.9$ & 0.44 \\
\hline Triglycerides $(\mathrm{mg} / \mathrm{dL})$ & $115(52-454)$ & $141(66-400)$ & 0.517 \\
\hline TSH $(\mu \mathrm{LU} / \mathrm{mg})$ & $0.7 \pm 1.09$ & $1.56 \pm 1.06$ & 0.228 \\
\hline AF: $\mathrm{Atrib}$ & \\
\hline
\end{tabular}

AF: Atrial fibrillation, GFR: Glomerular filtration rate, CRP: C-reactive protein, ESR: Erythrocyte sedimentation rate, LDL: Low-density lipoprotein, HDL: High-density lipoprotein TSH: Thyroid stimulating hormone 
63 studies of RF ablation, success rates in paroxysmal and persistent AF were $70 \%$ and $14.9 \%$, respectively ${ }^{7}$.

Excluding the first 3 months, 76.5\% of the patients with PAF in the present study were AF-free during a median follow-up of 22 months. In the STOP-AF study comparing cryoballoon ablation and antiarrhythmic medication, $69.9 \%$ of the patients in the ablation group were AF-free during the twelve months of follow-up ${ }^{8}$. In a prospective multi-center study by Stabile et al. ${ }^{9}$, the success rate at one year of follow-up was 56\% in the ablation group. The slightly higher success rate in the present study might have potentially resulted from the lower number of patients with structural heart disease, the relatively normal left atrium dimensions, and the small sample size.

In the above-mentioned meta-analysis of 63 studies investigating RF ablation, the reported rate of major complications was 4.9\%, with PV stenosis (1.6\%), pericardial effusion (0.6\%), and thromboembolism (0.3\%), which are the most frequent complications ${ }^{7}$. In another study on cryoablation, the rates of ischemic stroke, cardiac tamponade, and PV stenosis were reported as $0.3 \%, 0.3 \%$, and $0.17 \%$, respectively ${ }^{10}$. In the present study, none of the patients had major complications such as PV stenosis, cardiac tamponade, stroke, or death. Again, the lower complication rate in this study compared to the published data may be associated with the expertise level of our center in cryoballoon ablation for AF treatment, the limited number of patients, the inclusion of younger patients, and the lower number of comorbidities.

Pericardial effusion and phrenic nerve injury represent relatively more common complications of cryoablation. In the FIRE and ICE ${ }^{11}$ study, phrenic nerve injury was reported in 2.3\% of the cases. In the present study, 2 patients had pericardial effusion. Since none of the patients had the signs of cardiac tamponade, pericardiocentesis was not required.

Previously, an anterior-posterior LA diameter in the parasternal long-axis exceeding $45 \mathrm{~mm}$ was reported to be predictive for AF recurrence ${ }^{12}$. Aytemir et al. ${ }^{13}$ identified LA diameter as an independent predictor for AF recurrence in their study evaluating efficacy and safety endpoints after PV isolation with cryoablation. In the present study, the mean LA diameter in patients with and without AF recurrence was $44 \pm 6.6$ and $38 \pm 5.3 \mathrm{~mm}$, respectively. LA dimensions were predictive for long-term AF recurrence after cryoablation. This observation supports the notion that LA dimensions should be a part of the patient selection process before cryoablation procedures.

Patients with high LAA emptying and filling rates determined by transesophageal echocardiography were found to remain in sinus rhythm for longer periods during their follow-up ${ }^{14}$. In a multi-center prospective study, the LAA emptying rate of less than $40 \mathrm{~cm} / \mathrm{sec}$ was the single most important predictor of AF recurrence within 1 year ${ }^{15}$. In the current study, patients who developed recurrent AF had a $28 \mathrm{~cm} / \mathrm{sec}(22-55)$ LAA flow rate determined by transesophageal echocardiography before cryoablation. A low LAA flow rate correlated with a higher likelihood of late AF recurrence. In line with the previous reports, this observation points out the role of a high LAA flow rate in maintaining the sinus rhythm.

AMIO-CAT ${ }^{16}$ and EAST-AF ${ }^{17}$ studies found that short-term antiarrhythmic treatment after AF ablation did not affect longterm AF recurrence although it might reduce the frequency of atrial tachyarrhythmia during the first 3 months. Lee et al. ${ }^{18}$ found late AF recurrence among 35 of the 81 patients (43\%) who developed early recurrence. Aytemir et al. ${ }^{13}$ observed early AF recurrence in 29.1\% of the patients who had AF recurrence after PV isolation with cryoablation. In the present study, $37.5 \%$ of the patients with late AF recurrence had an early AF episode, supporting the notion that early AF episodes may predict late AF recurrences.

Kubala et al. ${ }^{19}$ performed cryoablation in 118 patients with drug-resistant PAF and found that atypical PV anatomy involving a common left PV was associated with an increased risk of AF recurrence compared to normal PV anatomy. There were 11 patients with PV anomalies in the present study. The rate was $37.5 \%{ }^{6}$ and $9.5 \% 0^{5}$ in the group with AF recurrence and in the group with maintained sinus rhythm, respectively. The presence of a common PV was associated with AF recurrence. This observation suggests that cryoablation may be associated with lower success rates among patients with PV anomalies.

In the study by Evranos et al. ${ }^{20}$, several biomarkers including C-reactive protein and erythrocyte sedimentation rate were found to not affect the risk of AF recurrence. Similarly, C-reactive protein and erythrocyte sedimentation rate measurements performed before cryoablation showed no association with AF recurrence in the present study.

Due to financial reasons, we could not use the three dimensional mapping system for ablation in our center. The three dimensional catheter navigation techniques can be applied to facilitate accurate catheter positioning with limited fluoroscopic exposure. The three dimensional mapping systems allow a better understanding of the anatomy and the pathophysiology of the arrhythmia ${ }^{21}$. In the complex patients, the combination of the three dimensional mapping system with image integration and remote magnetic navigation have been shown to be useful to facilitate ablation with very low fluoroscopy exposure. Integration of the fluoroscopy into the mapping system allows better understanding of the anatomy and might be associated with a better safety profile due to continuous catheter visualization during ablation ${ }^{22}$.

\section{Study Limitations}

This study had several limitations. This was a retrospective analysis. Because of the sample size, future studies of larger cohorts with more statistical power were needed to validate 
the findings. Some patients had a relatively short follow-up duration (8 months), and the predictive significance of the specified factors in patients with recurrent AF warrants further evaluation. Some asymptomatic AF cases may not have been included in the study.

\section{CONCLUSION}

Cryoablation is widely used for the treatment of AF worldwide. The safety and efficacy of this method have been established in several studies. However, the efficacy may vary depending on the expertise level of the operator, ablation technique, and catheter technology. Based on the results of the present study, several factors, including the occurrence of early AF episodes, history of cardioversion, use of multiple antiarrhythmic drugs before the procedure, high LA diameter, Iow LAA flow rate, presence of PV anomaly, increased interventricular septal thickness, left ventricular posterior wall thickness, and left ventricular mass, were predictive for $A F$ recurrence during follow up after cryoablation We believe that consideration of these factors during patient selection may improve the success rate of this procedure.

\section{Ethics}

Ethics Committee Approval: The study was approved by the Uludağ University Local Ethics Committee for Clinical Research with decree no: 2016-5/21 and approval date: 29.11.2019.

Informed Consent: Retrospective study.

Peer-review: Externally peer-reviewed.

\section{Authorship Contributions}

Surgical and Medical Practices: E.Ç., A.A., Concept: A.D., S.Ç., F.B., A.A., Design: E.Ç., A.A., Data Collection or Processing: E.Ç., Analysis or Interpretation: A.D., S.Ç., F.B., A.A., Literature Search: E.Ç., A.D., S.Ç., F.B., A.A., Writing: E.Ç., A.D., S.Ç., F.B., A.A.

Conflict of Interest: No conflict of interest was declared by the authors.

Financial Disclosure: The authors declared that this study received no financial support.

\section{References}

1. Naccarelli GV, Varker $\mathrm{H}$, Lin J, Schulman KL. Increasing prevalence of atrial fibrillation and flutter in the United States. Am J Cardiol. 2009;104:1534-9.

2. Kirchhof P, Benussi S, Kotecha D, Ahlsson A, Atar D, Casadei B, et al. 2016 ESC Guidelines for the management of atrial fibrillation developed in collaboration with EACTS. Eur Heart J. 2016;37:2893-62.

3. Camm AJ, Kirchhof P, Lip GY, Schotten U, Savelieva I, Ernst S, et al. Guidelines for the management of atrial fibrillation: the Task Force for the Management of Atrial Fibrillation of the European Society of Cardiology (ESC). Eur Heart J. 2010;31:2369-429.

4. Buch $P$, Friberg J, Scharling $H$, Lange $P$, Prescott E. Reduced lung function and risk of atrial fibrillation in the Copenhagen City Heart Study. Eur Respir J. 2003;21:1012-6.
5. Chen SA, Tai CT, Yu WC, Chen YJ, Tsai CF, Hsieh MH, et al. Right atrial focal atrial fibrillation: electrophysiologic characteristics and radiofrequency catheter ablation. J Cardiovasc Electrophysiol. 1999;10:328-35.

6. Lin WS, Tai CT, Hsieh MH, Tsai CF, Lin YK, Tsao HM, et al. Catheter ablation of paroxysmal atrial fibrillation initiated by non-pulmonary vein ectopy. Circulation. 2003;107:3176-83.

7. Calkins H, Reynolds MR, Spector P, Sondhi M, Xu Y, Martin A, et al. Treatment of atrial fibrillation with antiarrhythmic drugs or radiofrequency ablation: two systematic literature reviews and meta-analyses. Circ Arrhythm Electrophysiol. 2009;2:349-61.

8. Packer DL, Kowal RC, Wheelan KR, Irwin JM, Champagne J, Guerra PG, et al. Cryoballoon ablation of pulmonary veins for paroxysmal atrial fibrillation: first results of the North American Arctic Front (STOP AF) pivotal trial. J Am Coll Cardiol. 2013;61:1713-23.

9. Stabile G, Bertaglia E, Senatore G, De Simone A, Zoppo F, Donnici G, et al. Catheter ablation treatment in patients with drug-refractory atrial fibrillation: a prospective, multi-centre, randomized, controlled study (Catheter Ablation For The Cure Of Atrial Fibrillation Study). Eur Heart J. 2006;27:216-21.

10. Vogt J, Heintze J, Gutleben KJ, Muntean B, Horstkotte D, Nölker G. Longterm outcomes after cryoballoon pulmonary vein isolation: results from a prospective study in 605 patients. J Am Coll Cardiol. 2013;61:1707-12.

11. Kuck KH, Brugada J, Fürnkranz A, Metzner A, Ouyang F, Chun KR, et al. Cryoballoon or Radiofrequency Ablation for Paroxysmal Atrial Fibrillation. N Engl J Med. 2016;374:2235-45.

12. Theodorakis GN, Markianos M, Kouroubetsis CK, Livanis EG, Paraskevaidis IA, Kremastinos DT. Clinical, adrenergic and heart endocrine measures in chronic atrial fibrillation as predictors of conversion and maintenance of sinus rhythm after direct current cardioversion. Eur Heart J. 1996;17:550-6.

13. Aytemir K, Gurses KM, Yalcin MU, Kocyigit D, Dural M, Evranos B, et al. Safety and efficacy outcomes in patients undergoing pulmonary vein isolation with second-generation cryoballoont. Europace. 2015;17:379-87.

14. Wang T, Wang M, Fung JW, Yip GW, Zhang Y, Ho PP, et al. Atrial strain rate echocardiography can predict success or failure of cardioversion for atrial fibrillation: a combined transthoracic tissue Doppler and transoesophageal imaging study. Int J Cardiol. 2007;114:202-9.

15. Antonielli E, Pizzuti A, Pálinkás A, Tanga M, Gruber N, Michelassi $C$, et al. Clinical value of left atrial appendage flow for prediction of long-term sinus rhythm maintenance in patients with nonvalvular atrial fibrillation. J Am Coll Cardiol. 2002;39:1443-9.

16. Darkner S, Chen $X$, Hansen J, Pehrson $S$, Johannessen $A$, Nielsen JB, et al. Recurrence of arrhythmia following short-term oral AMIOdarone after CATheter ablation for atrial fibrillation: a double-blind, randomized, placebo-controlled study (AMIO-CAT trial). Eur Heart J. 2014;35:3356-64.

17. Kaitani K, Inoue K, Kobori A, Nakazawa Y, Ozawa T, Kurotobi T, et al. Efficacy of Antiarrhythmic Drugs Short-Term Use After Catheter Ablation for Atrial Fibrillation (EAST-AF) trial. Eur Heart J. 2016;37:610-8.

18. Lee SH, Tai CT, Hsieh MH, Tsai CF, Lin YK, Tsao HM, et al. Predictors of early and late recurrence of atrial fibrillation after catheter ablation of paroxysmal atrial fibrillation. J Interv Card Electrophysiol. 2004;10:221-6.

19. Kubala M, Hermida JS, Nadji G, Quenum S, Traulle S, Jarry G. Normal pulmonary veins anatomy is associated with better AF-free survival after cryoablation as compared to atypical anatomy with common left pulmonary vein. Pacing Clin Electrophysiol. 2011;34:837-43.

20. Evranos B, Aytemir K, Oto A, Okutucu S, Karakulak U, Şahiner L, et al. Predictors of atrial fibrillation recurrence after atrial fibrillation ablation with cryoballoon. Cardiol J. 2013;20:294-303.

21. Kim YH, Chen SA, Ernst S, Guzman CE, Han S, Kalarus Z, et al. 2019 APHRS expert consensus statement on three-dimensional mapping systems for tachycardia developed in collaboration with HRS, EHRA, and LAHRS. J Arrhythm. 2020;36:215-70.

22. Nagaraju L, Menon D, Aziz PF. Use of 3D Electroanatomical Navigation (CARTO-3) to Minimize or Eliminate Fluoroscopy Use in the Ablation of Pediatric Supraventricular Tachyarrhythmias. Pacing Clin Electrophysiol. 2016;39:574-80. 